\title{
VALUES UNDERPINNING A DEGROWTH TRANSFORMATION OF THE SOCIO-POLITICAL SYSTEM
}

\author{
MARIJA BRAJDIĆ VUKOVIĆ, BRANKO ANČIĆ AND \\ MLADEN DOMAZET
}

This paper deals with attitudes, values and ideologies as potentials in influencing cultural change toward more environmentally and socially sustainable socio-political system. The main framework of the discussion is the degrowth paradigm and the results of analyses are based on the two modules of the International Social Survey Program (2017). The main indicator of the (social) degrowth potentiality is the 'degrowth scale', consisting of dimensions related the end of economic growth and the need for social change. Those dimensions are (statistically) contextualised within respondents' socio-demographic characteristics, and their other values and attitudes, and discussed within the degrowth paradigm. Keywords: degrowth paradigm, cultural change, sustainable socio-political system, value systems, ideology, ISSP
Ta članek obravnava odnos, vrednote in ideologije, ki lahko potencialno vplivajo na kulturne spremembe $k$ bolj okoljsko in socialno trajnostnemu družbeno-političnemu sistemu. Glavni okvir razprave je paradigma odrasti, rezultati analiz pa temeljijo na dveh modulih mednarodnega programa socialnega raziskovanja (2017). Glavni kazalnik (družbene) narašcanja potenciala je "lestvica odrasti", povezana koncem gospodarske rasti in spotrebami po družbenih spremembah. Dimenzije odrasti so v razpravi (statistično) kontekstualizirane in se odražajo v socialno-demografskih značilnostih anketirancev in drugih njihovih vrednot in stališc.

Ključne besede: paradigma odrasti, kulturne spremembe, trajnostni družbenopolitični sistem, vrednostni sistemi, ideologija, ISSP

\section{INTRODUCTION}

This paper is a part of larger research project related to the development of the indicators that can describe current socio-bio-physical metabolisms of societies in order to offer a vision of a more sustainable future (Domazet 2019). This vision is theoretically nested within the degrowth paradigm. Degrowth is a relatively new term related to the scholarship that critiques the ideology behind the dogma of economic growth. As described by Kallis et al., economic growth is "an integrated cultural, political, ecological and economic process manifested as an increase in the total market value of all goods and services (GDP)", and degrowth, as its opposition is "a process of political and social transformation that reduces a societies throughput (the energy and resource flows in and out of an society) while improving the quality of life" (Kallis 2018: 292), because it decouples quality of life, especially at aggregate societal level, from flow of materials and energy. In our analysis the societies' potentiality for degrowth, or degrowth potentiality, is described and therefore 'measured' as an ability for development, achievement, or success that is partially used or not used at all, and related to the process of political and social transformation to reduce a societies' throughput. Our view of the degrowth potentiality is based on the theoretical and empirical research related to both economic growth and degrowth in the context of 
climate change, and its mitigation seen primarily through the lens of a radical restructuring of social infrastructure for maintenance and distribution of energy transformation.

It has been discussed and established that economic growth as a policy goal appeared in 1950s, and soon it became 'a bipartisan narrative that now transcends ideological divisions', and also furthermore, in terms of the depth of its internalization, it 'infiltrated everyday practices and became popular common sense' (Kallis et al. 2018: 295). According to historical analyses of the phenomena and its development and influence, in both political West and East, growth was used as an instrument by the political elite, although not in the same context. While in the West, growth was used to diffuse demands of the workers movements, in the East to excuse the lack of democracy and the failure of more revolutionary ambitions (Dale 2012; Purdey 2010; Schmelzer 2016). The most important tool of growth ideology is the calculation known as GDP, and studies show that its introduction was used as a means and gained dominance in making of nation states, in socio-economic and military conflicts, geopolitics and global uneven development (Waring 1999). Degrowth as a solution is defined by ecological economists as an equitable downscaling of throughput, with a concomitant securing of wellbeing. As Kallis et al. (2018: 298) propose, 'in future degrowth society, the economic is no longer center of everything; democracy is direct; surplus is expended for reproduction and fun; income and wealth are distributed according to egalitarian principles; vital resources, infrastructures and spaces are shared in common; technology is convivial and serves social purposes; resource throughput is minimized; and working hours are reduced by cutting consumption, production and wasteful expenditures'. From the description of the degrowth society it is obvious that it starts from the assumption that all societal changes are in its core cultural, and any society bases it potential for transformation in the possibilities of change of its dominant values.

This paper deals with the research problem of potentiality of a socio-political system to become more degrowth oriented and therefore realistically sustainable in the context of the climate change break down. Main goals of this paper are to a) explore socio-demographic characteristics of citizens that are inclined to highly value aspects of the degrowth attitude, b) explore which other values are connected in a broader attitude system that can be described as a transformative 'degrowth society' ideology, and c) to discuss the findings within the theoretical paradigm of the degrowth. We perceive that our analyses can give a clue which values should be supported and strengthened in a society in order for the degrowth social transformations to have a chance to succeed. The analysis presented in the paper is based on the results of the International Social Survey Program modules carried out in Croatia in 2018, Networks and The Role of Government. Main indicator of the (social) degrowth potentiality is the 'degrowth scale', constructed by the authors of this paper and added in the standard ISSP survey. 


\section{A CULTURAL CHANGE FOR THE BETTER (OR ONLY POSSIBLE) FUTURE}

There are recognized cultural, underlying problems of the Anthropocene, the geological epoch in which humans have in a brief time become a main geophysical force on the Earth (Steffen et al. 2007). Latour (1993) relates the problem of modernity to its constitution of reality through a strong separation between nature and culture, and critical theorists add to it the problem of all of the progress being powered by the fossil fuels and the expectations of capitalist production (Moore 2015; Malm 2016). Fossil fuel capitalism as a consequence of efforts by competitive capitalist production to lower the cost of input: primarily labour even at trade-off with energy in some cases, while accumulating profit, brought us dominance of economic values, especially of the growth paradigm, the exploitation of humans and alienation together with the modern illnesses. Today we face unprecedented environmental degradation, scarcity of essential materials, catastrophic loss of biological diversity and evolutionary pressures to the Earth's animal and plant species, global warming and climate change. Those are a direct result of the capitalist industrialisation and technological innovation as an instrument and utility of mass production and consumption, which resulted in ruthless exploitation of natural resources and huge amounts of carbon dioxide emissions, by-products such as fly ash, chemicals and microplastics.

However, concepts like Anthropocene and Climate change artificially universalise both the future and the past of humanity, dealing with the Earth as a whole world (Jasanoff 2015). In reality of the humans and non-humans occupying the Earth, the past is the one of colonisation, exploitation, subjugation and injustice. Present is localised in terms of exploitation and environmental degradation, of inequality and poverty, path dependent on the past and dependent on the future of environmental pollution, scarcity of natural resources, and climate change (sometimes combined). In such context, degrowth imaginary focuses its effort on localised principles that can be universally applied with localised adjustments. Those are an end of exploitation, direct democracy, localised production, reclaiming and sharing of the commons, unproductive expenditures (collective festives), diversification of economy, decommodification of labour and land (Kallis 2018).

Dominance of economic values in society supported/instantiated by Capitalism has influenced the personal life and life of families tremendously. Already at the beginning of the 20th century in Women's Suffrage and Class Struggle (1912), Rosa Luxemburg has observed that

[t]his kind of work (bringing up children and housework) is not productive in the sense of the present capitalist economy... no matter how enormous an achievement, the sacrifices and energy spent, the thousand little efforts add up to. This is but a private affair of the worker, his happiness and blessing, and therefore non-existent for our present society. As long as capitalism and the wage system rule, only that kind of work is considered as productive, which produces surplus value, which creates capitalist profit. (Hudis and Anderson 2004: 241). 
Today, the question of care, self-care, care for children, elderly and households, for the vulnerable members of society, is one of the central points in the degrowth paradigm thinking. As D'Alisa and Cattaneo (2013) argue, revaluation and redistribution of care work is vital for an equitable degrowth transition. Therefore the central points of the degrowth transition we focus on in our paper are related to norms and values in domains of economy, class, democracy, gender equality, relationships and care, including care for the environment.

\section{PARADIGMS, IDEOLOGIES AND ATTITUDES, VALUES AND BEHAVIOR}

In terms of understanding of what we are trying to discern from a certain kinds of social science data, collected in a certain manner, it is necessary to explain concepts used, that is: ideology, attitudes and values, and also what is the nature of connection of all of those.

According to Karl Mannheim implicit to the word ideology is “... the insight that in certain situations the collective unconscious of certain groups obscures the real conditions of society both to itself and to others and thereby stabilizes it. For Mannheim, this revelation arises from political conflict, in which "ruling groups in their thinking can become so interest-bound to a situation that they are simply no longer able to see certain facts which would undermine their sense of domination” (1949: 36). For Gramsci (2007) ideology is at once the obscure realm of common sense and the transparent sphere of individual and collective consciousness, and our historical and practical task is to make consciousness transparent. Ideology can become self-transparent through struggles, political positioning, and the establishment of collective goals.

However, we need a methodologically operational outlook on ideology in order to explore the possibilities of the concept and its uses. Because we use quantitative methodology and survey as a method, the easiest and most reliable approach to the measurement and explanations of the ideology concept is through much-used Eysenck's theory of the four levels of attitudes, an insight that he has acquired by performing factor analyses of political attitudes (Eysenck 1954). At the bottom there are specific opinions, "which are not in any way related to other opinions, which are not in any way characteristic of a person who makes them, and which are not reproducible" (Eysenck 1954: 111). Those are for example news media sites specific polls, related to everyday news. Habitual opinions are second level attitudes, those are reproducible and are more persistent on individual features, and are expressed through different specific opinions (e.g. attitudinal, Likert-scale measured statements in opinion polls). Attitude is built out of a number of related habitual opinions. Eysenck here gives an example of an anti-Semitic attitude, which consists of and is expressed through number of negative opinions on Jews. Attitudes are often not independent of other domains related attitudes, and together they form ideologies (Eysenck 1954: 112-113). For example, ethnocentrism, patriotism, pro-religious attitudes, strict bringing up of children etc. are often strongly positively correlated, and together form components of conservative ideology. We find Eysneck's methodological approach useful in trying to discern the degrowth ideology. 
This study, in its methodological organisation and ontological foundations, is not a case study. However in this particular paper, we use Croatia as a case. Thinking and writing about post-socialist Ex-Yugoslav countries, unavoidably guides us to the concepts of semiperiphery and post-socialist structure of societies (Domazet and Marinović Jerolimov 2014). Semi-periphery is a term for countries which mix both core and peripheral forms of organisation, transmit flows between core and peripheral regions, and exhibit cultural and social institutions' features intermediate in form between surrounding core and peripheral areas (Chase-Dunn and Hall 1997; Wallerstein 1998). Croatia is an interesting example of friction, co-production of different messy realities because universal claims related to capitalism and progressive norms and values are introduced and are in friction with the post-socialist environment, social institutions in transition, Roman-Catholicism as predominant religion, conservative but also progressive values and norms (see, e.g., Ringdal and Simkus 2012; Črpić and Zrinščak 2016). This friction with a complex environment and many opposing actors produces messy outcomes, as it does in such environments (Tsing 2005). Actors involved are not just social institutions but also natural resources and climate.

\section{METHODS}

Analyses presented in the paper are performed on the data from the International Social Survey Project modules Role of Government and Networks, which was conducted in Croatia in 2017. Sample of 1026 respondents is representative for the Croatian population in terms of age, sex and education. Degrowth scale battery, consisting of variables in forms of statements measured on the Likert scale, was constructed out of the questions used internationally in different surveys and was added to the internationally standardised modules questionnaire.

\section{INSTRUMENTS}

Socio-demographics (Independents): Age in years of respondents at the time of conducting of research. Education was measured as a total number of years of formal education. Personal income refers to self-reported monthly personal income average of respondent. Urban-rural place of residence was assessed by the following categorical variable: 1- "a big city", 2 - "a suburb or a outskirt of a big city", 3 - "a town or a small city", 4 - "a village". Political left-right preference is recoded from the variable that collected answers on the party respondents voted for on the last parliamentary elections in Croatia (in 2016). Parties were recorded in 1 - left, 2 - centre and 3 - right. Religiosity is measured through the question related to church attendance, from -1 several times a week or more often, to 8 - never. 
Dependents: Government spending is assessed with the questions if government should spend a money on environment; health; police and law enforcement; military and defence; old age pensions; unemployment benefits; culture and arts; and results are measured on a scale from 1 - "spend much less" to 5 - "spend much more". Government responsibility is assessed with the questions if government should be responsible for providing job for everyone; control prices; provide health care for sick; provide living standard for the old; help industry grow; provide living standard for unemployed; reduce income differences rich/poor; financial help to students; provide decent housing; laws to protect environment; promote equality between men/women. Results are measured on a scale from 1 - "definitely should not be responsible" to 4 - "definitely should be responsible". Interest in politics is assessed with the question on how interested is the respondent in politics on the scale from 1 - "not interested at all" through 5 - "very interested". Citizens' power over government is assessed with the opinion "People like me have no say in what government does" and with a scale from 1 - "strongly agree" to 5 - "strongly disagree". Understanding of politics relates to the answer to opinion "I have a good understanding of political issues" choosing from 1 - strongly disagree to 5 - strongly agree. Redistribution is measured on four variables - opinions, "Differences in income are too large", "Differences in people's standard of living should be small in fair societies", "It is the responsibility of the government to reduce the differences in income between people with high and low incomes", "Social benefits make people lazy". Results were measured on the Likert scale from 1 - "strongly disagree" through 5 - "strongly agree". Care is measured on three variables - opinions, "Adult children have a duty to look after their elderly parents", "Take care of yourself and family comes first, before helping others" and "People better off should help friends who are less well of". Results were measured on the Likert scale from 1 - "strongly disagree" through 5 - "strongly agree".

Degrowth scale(s): There are nine items that are included in the questionnaire and that are used in our analysis that represent the degrowth attitudes, as constructed by the authors of this study and based on previous research surveys (Drews and Van den Bergh 2016, EVS 2015). The items that measure degrowth in the factor analysis, varimax rotation, are loaded on three components, therefore we recognize that the degrowth scale consists of obvious three dimensions. The three dimensions are highly positively correlated (degrowth 1 and degrowth 2, r=.303, p>0.001, degrowth 2 and degrowth $3 \mathrm{r}=.220, \mathrm{p}>0.001$, degrowth 1 and degrowth $3 \mathrm{r}=.195, \mathrm{p}>0.001)$. Those are:

Factor degrowth 1 consisting of the following items: 1 . Climate change and other environmental problems will sooner or later result in an end to economic growth; 2 . Limited availability of natural resources (e.g. oil, gas) will sooner or later result in an end to economic growth; 3. Economic growth always harms the environment; 4 . To contribute to the fair mitigation of global climate change Croatia must reduce its $\mathrm{CO} 2$ emissions. Answers are measured on a Likert scale ranging from 1 - "completely disagree" through 5 - "completely agree". These items are highly saturated on the single factor (48\% of variance explained, .69 average factor loading). Cronbach alpha in the procedure for the additive scale constructed 
for the items is .63. A higher result on the scale signifies being more inclined to end economic growth for the purpose of preserving or mitigating the environment, therefore we have named the scale "Degrowth - the end of growth".

Factor degrowth 2 consisting of the following items: 1. Current global economic system is unsustainable; 2 . In order to have just and sustainable economy a deep societal change is required; 3. To reduce poverty we need to redistribute money and material possession. Answers are measured on a Likert scale ranging from 1 - "completely disagree" through 5 - "completely agree". These items are highly saturated on the single factor ( $49 \%$ of variance explained, .70 average factor loading). Cronbach alpha in the procedure for the additive scale constructed for the items is .48. A higher result on the scale signifies being more in favour of social and economic change and we have named the scale "Degrowth - the need for social and economic change".

Factor degrowth 3 consisting of the following items: 1 . We need to put less emphasis on money and material possessions; 2. People should spend less time in paid work and more in voluntary community activities/engagement. Answers are measured on a Likert scale ranging from 1 - "completely disagree" through 5 - "completely agree". These variables are highly saturated on the single factor (61\% of variance explained, .77 average factor loading). Cronbach alpha in the procedure for the additive composite constructed for the items is .36. A higher result on the composite signifies being more inclined to abolish materialist values and we have named the composite "Degrowth - a non-materialist turn".

Of additive scales that represent the degrowth as an empirical concept in our research, 'the end of growth' is the strongest, and 'a non-materialist turn' weakest dimension in terms of its statistical power. Of all of the instruments from the ISSP Croatia Role of government and Networks dataset used in our analyses, only the degrowth scale was partially used in the analyses presented in the paper Domazet (2019).

\section{RESULTS}

First, we were interested in the distribution of the respondents concerning dimensions and computed scales, especially for those who agree and agree strongly with all of the statements. There are 285 respondents (27.8\%) who agree (4) and/or agree completely (5) with the statements related to the end of growth scale. The statements of the scale of a need for social and economic change are supported with (completely) agree answers by 635 respondents (61.8\% of the sample), and there are 251 (24,5\%) respondents who have answered that they agree or completely agree with the statements of the composite called a non-materialist turn. There are 88 respondents strongly supporting (answering 4 agree and 5 completely agree) all variables of the degrowth scale. Combined the end of growth and a need for social and economic change are supported with (completely) agree answers by 229 respondents. The end of growth and a non-materialist turn are supported in combination by 105 respondents, 
and a need for social and economic change and a non-materialist turn by 191 respondents. Out of the numbers, it is obvious that a need for social and economic change is the most supported dimension of the researched degrowth concept. However, in our analyses we were interested in possible other attitudes that are supported by all (degrowth) respondents no matter the dimension(s) of the degrowth they are supporting the most.

\section{ANALYSIS RELATED TO SOCIO-DEMOGRAPHIC VARIABLES}

We briefly describe the demographics of the respondents, divided by the three scales, in order to learn something more about our "target" population. First, we present results for the scale, and then discuss a bit about the respondents who are an 'extreme' on this dimension in the sense that they agree, or completely agree with all of the related statements.

We have tested for significant differences/correlations for degrowth scales 1, 2 and 3 , related to sex, age, and education of respondent, personal income, urban-rural type of setlement, political preference and religiosity (church attendance). Related to "the end of growth" scale, there is significant effect for age, education and sex of respondent, showing that this type of thinking is more supported by older respondents $(\mathrm{r}=.107, \mathrm{p}=0.001)$, by less educated $(-.130, \mathrm{p}=0.000)$ and more by female respondents $(\mathrm{t}(960)=3.05, \mathrm{p}=0.002)$. Also by respondents with lower personal income $(r=-.134, p=0.000)$. Frequency of church attendance and the size of settlement where respondents live has no significant effect on their attitudes, left-right party preference has no significant effect. Regarding the scale of "a need for social and economic change" significant effects are found for age and education of respondents. Older respondents, and more educated, are supporting this view more $(\mathrm{r}=174$, $\mathrm{p}=0.000 ; \mathrm{r}=076, \mathrm{p}=0.017)$, and those who have lower personal income $(\mathrm{r}=-.087, \mathrm{p}=0.006)$. There is also a significant, albeit quite weak effect related party preference in a way that left voters are supporting this attitude more (score higher on a scale) $(r=-.090, p=0.032)$. There are no significant effects for other tested independents. Somewhat different outcome is for the scale "a non-materialist turn", for which significant effects are for the type of place of residence, those from more urban settlements support this view significantly more often $(\mathrm{F}(3)=3.64, \mathrm{p}=0.012)$.

As mentioned before, there are 88 respondents who agreed and strongly agreed with all of the statements on the degrowth scale, on all three dimensions. Those are slightly more female (51\%) compared to male respondents, their average age is 50 years old, mostly they have completed high school, and they often live in a more rural settlements $(52 \%)$.

In our analyses presented in this paper we were interested in possible other attitudes that are supported by all (degrowth) respondents no matter the dimension(s) of the degrowth they are supporting the most. 


\section{OPINIONS RELATED TO THE DEGROWTH IDEOLOGY}

First we discuss respondents opinions related to the government-spending (table 1) and responsibility (table 2). We have built six linear regression models, two for each scale as criteria, and with including of the usual suspects - age, sex, education, place of residence and income as the standard socio-demographic block. Those models are weak in terms of their statistical power, but are offering us an outlook on the most important topics related to our dimensions/attitudes of the degrowth ideology (measured on scales) in the domains of governments' spending and responsibility.

As can be seen from the table 1, significant correlates of the end of growth scale/attitude are the opinion that government should spend money on environment. For the scale a need for social and economic change, significant is health, old age pensions, and education, and those supporting the scale are significantly opposing spending on military and defence. Those are significantly older respondents, which possibly explains selection of old age pensions in top priorities. For those supporting the composite a non-materialist turn, government should also spend money on environment, but also culture and arts.

Table 1. Correlates of attitudes toward the degrowth dimensions: government spending

\begin{tabular}{|l|l|l|l|}
\hline & The end of growth & $\begin{array}{l}\text { A need for social and } \\
\text { economic change }\end{array}$ & $\begin{array}{l}\text { A non-materialist } \\
\text { turn }\end{array}$ \\
\cline { 2 - 4 } & Betta coefficients/(p<) & Betta coefficients/(p<) & Betta coefficients/(p<) \\
\hline Age & $-0,039$ & $\mathbf{, 1 2 8}(\mathbf{p}<\mathbf{. 0 0})$ & $-0,039$ \\
\hline Sex $(2$ Female) & $\mathbf{, 0 6 5}(\mathbf{p}<\mathbf{. 0 5})$ & 0,044 & $-0,017$ \\
\hline Education $(0$ No school -7 Phd) & $\mathbf{- , 0 9 9}(\mathbf{p}<\mathbf{. 0 1})$ & $\mathbf{, 0 8 5}(\mathbf{p}<\mathbf{. 0 1})$ & 0,041 \\
\hline Urban-rural place of residence & $-0,008$ & $-0,048$ &,$- \mathbf{0 7 3}(\mathbf{p}<. \mathbf{0 5})$ \\
\hline $\begin{array}{l}\text { Income (monthly averge in } \\
\text { kuna) }\end{array}$ & $\mathbf{- , 0 9 6}(\mathbf{p}<\mathbf{. 0 5})$ &,- 028 & $-0,022$ \\
\hline $\begin{array}{l}\text { Government should spend } \\
\text { money: environment }\end{array}$ & $\mathbf{, 1 3 4}(\mathbf{p}<\mathbf{. 0 0})$ & 0,047 & $\mathbf{, 0 9 7}(\mathbf{p}<. \mathbf{0 1})$ \\
\hline $\begin{array}{l}\text { Government should spend } \\
\text { money: health }\end{array}$ & 0,054 & $\mathbf{, 1 4 9}(\mathbf{p}<\mathbf{. 0 0})$ & 0,024 \\
\hline $\begin{array}{l}\text { Government should spend } \\
\text { money: police and law } \\
\text { enforcement }\end{array}$ & 0,02 & $-0,036$ & 0,031 \\
\hline $\begin{array}{l}\text { Government should spend } \\
\text { money: education }\end{array}$ & 0,014 & $\mathbf{, 0 8 0}(\mathbf{p}<\mathbf{. 0 5})$ & 0,001 \\
\hline $\begin{array}{l}\text { Government should spend } \\
\text { money: military and defence }\end{array}$ & 0,009 & $-\mathbf{0 9 7}(\mathbf{p}<\mathbf{. 0 1})$ &,- 022 \\
\hline
\end{tabular}




\begin{tabular}{|l|l|l|l|}
\hline $\begin{array}{l}\text { Government should spend } \\
\text { money: old age pensions }\end{array}$ & 0,052 & $\mathbf{, 1 5 8}(\mathbf{p}<\mathbf{. 0 0})$ & $-0,024$ \\
\hline $\begin{array}{l}\text { Government should spend } \\
\text { money: unemployment } \\
\text { benefits }\end{array}$ & 0,038 & $-0,056$ & 0,001 \\
\hline $\begin{array}{l}\text { Government should spend } \\
\text { money: culture and arts }\end{array}$ & 0,057 & 0,053 & $\mathbf{, 1 0 4}(\mathbf{p}<. \mathbf{0 1})$ \\
\hline F-ratio & 6,544 & 13,075 & 3,431 \\
\hline F-sig. & .000 & .000 & .000 \\
\hline$R^{2}$ & 0,089 & 0,15 & 0,035 \\
\hline Adjusted $R^{2}$ & 0,077 & 0,14 & 0,024 \\
\hline
\end{tabular}

Regarding the question on what should the government be responsible for, for all three scales there is (significant) expressed opinion that it should be for environmental laws and for the provision of decent housing for everyone. In addition, together with the support for the end of growth attitude and a need for social and economic change attitude, grows the support for the government responsibility for the reduction of the income differences for all.

Table 2. Correlates of attitudes toward the degrowth dimensions: government responsibility

\begin{tabular}{|l|l|l|l|}
\hline & The end of growth & $\begin{array}{l}\text { A need for social and } \\
\text { economic change }\end{array}$ & $\begin{array}{l}\text { A non-materialist } \\
\text { turn }\end{array}$ \\
\cline { 2 - 4 } & Betta coefficients/(p<) & Betta coefficients/(p<) & Betta coefficients/(p<) \\
\hline Age & 0,052 & 0,138 & $-0,033$ \\
\hline Sex $(2$ Female) & $\mathbf{, 0 7 8}(\mathbf{p}<\mathbf{. 0 5})$ & 0,041 & $-0,014$ \\
\hline Education $(0$ No school -7 Phd) & $\mathbf{- , 0 7 2}(\mathbf{p}<\mathbf{. 0 5})$ &, 114 & 0,05 \\
\hline Urban-rural place of residence & $-0,019$ & $-0,045$ &,$- \mathbf{0 7 5}(\mathbf{p}<. \mathbf{0 5})$ \\
\hline $\begin{array}{l}\text { Income (monthly averge in } \\
\text { kuna) }\end{array}$ & $\mathbf{- , 0 8 2}(\mathbf{p}<\mathbf{. 0 5})$ &,- 058 & 0,006 \\
\hline $\begin{array}{l}\text { Government responsibility: } \\
\text { provide job for everyone }\end{array}$ & $\mathbf{, 0 8 3}(\mathbf{p}<\mathbf{. 0 5})$ & 0,049 & 0,035 \\
\hline $\begin{array}{l}\text { Government responsibility: } \\
\text { control prices }\end{array}$ & $\mathbf{, 1 0 6}(\mathbf{p}<\mathbf{. 0 1})$ & $-0,059$ & $-0,042$ \\
\hline $\begin{array}{l}\text { Government responsibility: } \\
\text { provide health care for sick }\end{array}$ & 0,011 & 0,012 & $-0,017$ \\
\hline $\begin{array}{l}\text { Government responsibility: } \\
\text { provide living standard for } \\
\text { the old }\end{array}$ & $-0,06$ & 0,065 & $-0,081$ \\
\hline $\begin{array}{l}\text { Government responsibility: } \\
\text { help industry grow }\end{array}$ & 0,056 & 0,074 & 0,007 \\
\hline
\end{tabular}




\begin{tabular}{|c|c|c|c|}
\hline $\begin{array}{l}\text { Government responsibility: } \\
\text { provide living standard for } \\
\text { unemployed }\end{array}$ & 0,014 & $-0,029$ & 0,102 \\
\hline $\begin{array}{l}\text { Government responsibility: } \\
\text { reduce income differences } \\
\text { rich/ poor }\end{array}$ &, $086(\mathrm{p}<.05)$ &, $182(\mathrm{p}<.05)$ & 0,116 \\
\hline $\begin{array}{l}\text { Government responsibility: } \\
\text { financial help to students }\end{array}$ & $-0,055$ & 0,023 & $-0,032$ \\
\hline $\begin{array}{l}\text { Government responsibility: } \\
\text { provide decent housing }\end{array}$ &, $105(\mathrm{p}<.01)$ &, $132(\mathrm{p}<.01)$ &,$- 033(p<.01)$ \\
\hline $\begin{array}{l}\text { Government responsibility: } \\
\text { laws to protect environment }\end{array}$ &, $081(\mathrm{p}<.05)$ &, $011(\mathrm{p}<.05)$ &,$- 014(\mathrm{p}<.05)$ \\
\hline $\begin{array}{l}\text { Government responsibility: } \\
\text { promote equality between } \\
\text { men/ women }\end{array}$ & $-0,061$ & 0,016 & 0,05 \\
\hline F-ratio & 7,753 & 12,095 & 4,095 \\
\hline$F$-sig. & .000 & .000 & .000 \\
\hline$R^{2}$ & 0,124 & 0,17 & 0,054 \\
\hline Adjusted $R^{2}$ & 0,109 & 0,156 & 0,038 \\
\hline
\end{tabular}

Second, we discuss opinions on social and economic redistribution (table 3). Again, models are not strong in terms of their statistical power, but are still the source of important insights. With the growth of results on all of the three degrowth scales - composites/ attitude dimensions, grows the support for the thinking that differences in peoples standard of living should be small in fair societies, and that the responsibility of government is to reduce differences in incomes. In addition with the support for the end of growth scale, grows the inclination for respondents to believe that social benefits make people lazy. In addition, with the support for a need for social and economic change scale grows the support for the opinion that differences in income are too large.

Table 3. Correlates of attitudes toward the degrowth dimensions: social and economic redistribution

\begin{tabular}{|l|l|l|l|}
\hline & The end of growth & $\begin{array}{l}\text { A need for social and } \\
\text { economic change }\end{array}$ & $\begin{array}{l}\text { A non-materialist } \\
\text { turn }\end{array}$ \\
\cline { 2 - 4 } & Betta coefficients/(p<) & Betta coefficients/(p<) & Betta coefficients/(p<) \\
\hline Age & 0,035 & $\mathbf{, 0 8 7}(\mathbf{p}<\mathbf{. 0 1})$ & $-0,047$ \\
\hline Sex (2 Female) & $\mathbf{, 0 8 7}(\mathbf{p}<\mathbf{. 0 1})$ & 0,053 & $-0,005$ \\
\hline Education (0 No school -7 Phd) & $\mathbf{- , 0 8 3}(\mathbf{p}<\mathbf{. 0 5})$ & $\mathbf{, 1 2 1}(\mathbf{p}<\mathbf{. 0 0})$ & 0,053 \\
\hline Urban-rural settlement & $-0,029$ & $-0,049$ & $\mathbf{- , 0 7 2}(\mathbf{p}<\mathbf{. 0 5})$ \\
\hline
\end{tabular}




\begin{tabular}{|l|l|l|l|}
\hline $\begin{array}{l}\text { Income (monthly averge in } \\
\text { kuna) }\end{array}$ & $\mathbf{- , 0 7 3}(\mathbf{p}<\mathbf{. 0 5})$ &,- 035 & $-0,002$ \\
\hline $\begin{array}{l}\text { Differences in income are too } \\
\text { large }\end{array}$ & 0,056 & $\mathbf{1 8 5}(\mathbf{p}<\mathbf{. 0 0})$ & $-0,032$ \\
\hline $\begin{array}{l}\text { Differences in people's stand- } \\
\text { ard of living should be small } \\
\text { in fair societies }\end{array}$ & $\mathbf{, 1 2 8}(\mathbf{p}<\mathbf{. 0 1})$ & $\mathbf{, 1 4 9}(\mathbf{p}<\mathbf{. 0 0})$ & $\mathbf{, 1 3 1}(\mathbf{p}<\mathbf{. 0 1})$ \\
\hline $\begin{array}{l}\text { It is the responsibility of the } \\
\text { government to reduce the } \\
\text { differences in income between } \\
\text { people with high and low } \\
\text { incomes }\end{array}$ & $\mathbf{, 1 1 5}(\mathbf{p}<\mathbf{. 0 1})$ & $\mathbf{2 0 2}(\mathbf{p}<\mathbf{. 0 0})$ &, $\mathbf{0 8 7}(\mathbf{p}>\mathbf{. 0 5})$ \\
\hline $\begin{array}{l}\text { Social benefits make people } \\
\text { lazy }\end{array}$ & $\mathbf{1 1 2}(\mathbf{p}<\mathbf{. 0 0})$ & 0,087 & $-0,055$ \\
\hline F-ratio & 20,962 & 59,655 & 8,122 \\
\hline F-sig. & .000 & .000 & .000 \\
\hline$R^{2}$ & 0,121 & 0,235 & 0,042 \\
\hline Adjusted $R^{2}$ & 0,113 & 0,228 & 0,033 \\
\hline
\end{tabular}

Following analyses, six models, are related to opinions on politics and on practices of care for others. In the first three models (table 4) we can see that for all three scales interest in politics is not significant. The results of the end of growth scale rise together with the results of the opinion that respondent him/herself has no say about what the government does. It is similar for the scale a need for social and economic change, while for the third composite the result is, interestingly, opposite. The first scale also has significant effect for the perceived (not) good understanding of political issues.

Table 4. Correlates of attitudes toward the degrowth dimensions: interest in politics and perceived democratic potential

\begin{tabular}{|l|l|l|l|}
\hline & The end of growth & $\begin{array}{l}\text { A need for social and } \\
\text { economic change }\end{array}$ & $\begin{array}{l}\text { A non-materialist } \\
\text { turn }\end{array}$ \\
\cline { 2 - 4 } & Betta coefficients/(p<) & Betta coefficients/(p<) & Betta coefficients/( $<$ <) \\
\hline Age & $\mathbf{, 0 9 3}(\mathbf{p}<\mathbf{. 0 1})$ & $\mathbf{, 1 3 7}(\mathbf{p}<\mathbf{. 0 0})$ & $-0,032$ \\
\hline Sex (2 Female) & 0,079 & $\mathbf{, 0 6 6}(\mathbf{p}<\mathbf{. 0 5})$ & 0,007 \\
\hline Education (0 No school -7 Phd) & $\mathbf{- , 1 1 0}(\mathbf{p}<\mathbf{. 0 1})$ & $\mathbf{, 0 7 9}(\mathbf{p}<\mathbf{. 0 5})$ & 0,043 \\
\hline Urban-rural place of residence & $-0,016$ & $-0,034$ & $-0,079$ \\
\hline $\begin{array}{l}\text { Income (monthly average in } \\
\text { kuna) }\end{array}$ & $\mathbf{- , 0 8 9}(\mathbf{p}<\mathbf{. 0 1})$ & $\mathbf{- , 0 7 9}(\mathbf{p}<\mathbf{. 0 5})$ &,- 021 \\
\hline How much interested in politics & 0 & $-0,004$ & 0,027 \\
\hline
\end{tabular}




\begin{tabular}{|l|l|l|l|}
\hline $\begin{array}{l}\text { People like me have no say } \\
\text { about what government does }\end{array}$ & $\mathbf{, 0 7 4}(\mathbf{p}<\mathbf{. 0 1})$ & $\mathbf{, 1 5 8}(\mathbf{p}<\mathbf{. 0 0})$ & $\mathbf{- , 0 9 0}(\mathbf{p}<\mathbf{. 0 1})$ \\
\hline $\begin{array}{l}\text { Good understanding of politi- } \\
\text { cal issues }\end{array}$ & $\mathbf{- , 0 8 4}(\mathbf{p}<\mathbf{. 0 5})$ &, 067 & 0,007 \\
\hline F-ratio & 3,952 & 7,172 & 2,522 \\
\hline F-sig. & .000 & .000 & .000 \\
\hline$R^{2}$ & 0,057 & 0,76 & 0,2 \\
\hline Adjusted $R^{2}$ & 0,49 & 0,68 & 0,12 \\
\hline
\end{tabular}

The last three models are related to the care for others (table 5), and we find that the opinion that people better off should help their friends is highly positively correlated with all three scales/attitudes. In addition, for the composite a non materialist turn there is significant negative correlation for the opinion that one should take care of him/herself and family first, before helping others, meaning that those agreeing with the opinions on a non-materialist turn composite support such view less often.

Table 5. Correlates of attitudes toward the degrowth dimensions: Care for others

\begin{tabular}{|c|c|c|c|}
\hline & The end of growth & $\begin{array}{l}\text { A need for social and } \\
\text { economic change }\end{array}$ & $\begin{array}{l}\text { A non-materialist } \\
\text { turn }\end{array}$ \\
\hline & Betta coefficients/(p<) & Betta coefficients/(p<) & Betta coefficients/(p<) \\
\hline Age & 0,061 &, $150(\mathrm{p}<.000)$ & $-0,031$ \\
\hline Sex (2 Female) &, $101(\mathrm{p}<.010)$ &, $072(\mathrm{p}<.050)$ & 0,005 \\
\hline Education (0 No school -7 Phd) &,$- 097(p<.010)$ &, $105(\mathrm{p}<.010)$ & 0,046 \\
\hline Urban-rural settlement & $-0,009$ & $-0,048$ &,$- 072(\mathrm{p}<.050)$ \\
\hline $\begin{array}{l}\text { Income (monthly averge in } \\
\text { kuna) }\end{array}$ & $-0,086$ & $-0,054$ & $-0,011$ \\
\hline $\begin{array}{l}\text { Adult childern have a duty to } \\
\text { look after their elderly parents }\end{array}$ & 0,02 & 0,063 & $-0,004$ \\
\hline $\begin{array}{l}\text { Take care of yourself and } \\
\text { family first, before helping } \\
\text { others }\end{array}$ & 0,021 & 0,047 &,$- 076(p<.050)$ \\
\hline $\begin{array}{l}\text { People better off should help } \\
\text { friends who are less well of }\end{array}$ &, $167(\mathrm{p}<.000)$ &, $125(\mathrm{p}<.000)$ &, $171(\mathrm{p}<.000)$ \\
\hline$F$-ratio & 10,685 & 9,976 & 10,675 \\
\hline F-sig. & .000 & .000 & .000 \\
\hline$R^{2}$ & .076 & .077 & .041 \\
\hline Adjusted $R^{2}$ & .068 & .069 & .034 \\
\hline
\end{tabular}




\section{INSIGHTS AND CONCLUSION}

Let us briefly see what we have achieved in Eysenck's (1954) terms. We have started with data on the habitual opinions of respondents of what we have called (based on previous theoretical and research work of many authors) the degrowth construct. Factor analysis extracted three dimensions/attitudes, those attitudes are related to recognition of the need for the end of economic growth, recognition of the need of society to make a social change, and last, recognition that society has to become less materialistically oriented. All those attitudes are highly correlated with each other. Next we have found habitual opinions that are also significantly correlated to the degrowth attitudes, that we assume are also a part of attitudes related to the degrowth ideology (D'Alisa et al. 2014; Kallis 2018). Those are from the domain of attitudes on economics (1), social justice and inequality (4), the role of government (6), democracy (1), social care (3) and environmental care (2). We have also found that a number of habitual opinions are not significantly correlated to our degrowth attitudes, and we find those to be important additions in understanding of what the degrowth ideology is, primarily in Croatian society, and second in its aspects in other societies as well. We find that our findings support a theoretical notion that the degrowth ideology is the one that requests economic redistribution together with the provision of decent living for all of the members of society. In addition, in aspects it is an ideology of care for friends, and certainly for the environment. It values non-material aspects of everyday life, such as arts and culture. There is no clear ideological orientation in terms on left or right on the political spectrum, at least does not appear so in Croatia, although there is slight trend of leaning toward left parties, but this should be further explored. There is also a lack of confidence, at least in some measure, in one's own political power and knowledge of politics, and no significant interest in politics is expressed. Whether this signifies disbelief in representative democracy and politics per se, or just disappointment with Croatian everyday politics is an issue that should be explored in future research.

As results have shown, older generations support attitudes/dimensions of the degrowth ideology more than the younger. However, the Croatian nation is growing significantly older, just as the other nations in the developed world that is most enjoined to alter material and energy flows, therefore reflection and expressed support for change in the older generation could be more of an asset than a problem. In addition, because of the dispersion of results related to education, and sex of respondents, their personal income and place of residence, we perceive that there is almost equal potential for development of aspects of the degrowth attitudes within the whole population. That is, we perceive that this degrowth attitude inclination is more related to the other experiences and opinions of citizens, and less to their demographics.

As we perceive the three dimensions to be a part of the higher-level construct - the degrowth ideology, we find that other attitudes found to be significant in our analyses are also a part of the degrowth ideology, that is: support the degrowth orientation. We base this understanding on the fact that those attitudes are equally or mostly supported by the 
respondents no matter the dimension of the degrowth scale they support the most. Those are first of all support for the income redistribution, for government spending on environment, and responsibility of government for the environmental laws. Also significant support for the government responsibility in reduction of income differences between rich and poor, and provision of decent housing for all. Significantly more supported by the respondents is also the opinion that one should help one's friends if one is better off, however they do not significantly differ in an attitude on the necessity of helping one's elderly parents, but also there's no significant effect related to whether one should help one's family above all other people. Significant disbelief in democracy is expressed, in terms of the lack of belief in the power of one's own voice in politics, and there is no significant interest in politics and some of them express belief that they do not understand politics well.

Related to the questions of care, one can find it puzzling that the care for elderly is not significantly correlated with the attitudes of the degrowth ideology. However, because in the entire sample this opinion is very highly supported (over $80 \%$ of respondents agrees and completely agrees), in that sense those who are scoring highly on the degrowth related attitudes do not differ significantly from those who do not. The same is with an opinion related to the care of the one's family coming before care for the other members of society, which is supported (scoring 4 or 5 ) by $90 \%$ of the respondents in the sample. Therefore, there is not enough of the variability in the population for this to be significant in the case of the degrowth supporters. But we can still discern that those supporting the degrowth are in more supporting the concept of solidarity because they significantly more hold that one should help his/hers friends if one is financially better off. The support of solidarity, as an attitude related to degrowth also one should explore further with questions more sensitive to different types of thinking within the (Croatian) population.

Looking back at the degrowth concept, and its central points of reference related to cultural change (D’Alisa et al. 2014; Kallis 2018), in Croatian society we find some potentiality for the degrowth society. As Kallis had noted in his book on the degrowth (2018), referring to Latouche (2009) and D'Alisa et al. (2014) "those who use the term (degrowth) signify something bigger, a vision or imaginary of an alternative world" (Kallis et al. 2018: 117). In his (utopian) thinking, possible degrowth future “...decentres the economic and re-embeds it within the social and the political. Human activity and work in degrowth imaginary are centred around the care for other humans... economc is not the end in itself, but a means to superior end: the satisfaction of our biological needs and our quest for meaning" (Kallis et al. 2018: 118). Author's principles of the degrowth utopia include: ending of the exploitation, direct democracy, localised production, sharing of the commons, strong relationships, slowing of the expense of natural material, principle of care, diversifying of the economy, and decommodification of the land and value. We go a bit further by saying that such society needs values that support these processes. In our research on the Croatian sample we have found values that support ending of exploitation, importance of commons, valuing of nature, and valuing principles of care and of relationships. It is 
however obvious that the concept of the degrowth is much more complex and that we will need further research to describe this value systems (attitudes) that support it more thoroughly. For example, related to the principle of care, today most of the care-work falls disproportionately on women, especially poor women who take care of their own and other people's households. We find in our research some of values supporting principles of care, but have not researched the most important dimension of it, and that is the one related to gender roles and inequality. Also as D'Alisa et al. (2014) propose that care should move to the public sphere, be shared collectively where possible, e.g. the childcare sharing groups, or co-housing projects with provision for elders. Unpaid care work would be valued in a way that this hierarchy of value of labour would be inverted. Care should also extend beyond the reproduction of human species, it should be concentrated also on caring for other living beings and species. Values that support such type of society are from the domain of private - public lives and wellbeing, together with the lifestyle choices, which we were not collecting in our modules. Therefore, we intend to explore further through different statistical procedures and possibilities to which possible values from other domains of culture the degrowth construct corresponds, or belongs to.

So, as explained there are limitations to this research, mainly related to the fact that all of the researched opinions should be further expanded to form attitudes in Eysneck's (1954) sense, and in order to better clarify and support dimensions of the degrowth ideology such as are in the domains of care, democracy and political preferences and opinions. However, our instruments, analyses and research, and furthermore our approach to the topic of the degrowth ideology, can be useful in future research that aims to establish scheme of valuable attitudes that should be developed, and where developed supported (through education, advocacy and political action) for any society to have a chance for cultural transformation towards the degrowth society.

\section{REFERENCES}

Anderson, Kevin, and Peter Hudis. 2004. The Rosa Luxemburg Reader. New York: Monthly Review Press. Campbell, James. 1986. Essays in Anglo-Saxon History. London, UK: The Hambledon Press.

Chase-Dunn, Christopher, and Thomas, D. Hall. 1997. Rise and Demise: Comparing World Systems. Abingdon: Routledge.

Črpić, Gordan, and Siniša Zrinščak. 2010. Dinamičnost u stabilnosti: religioznost u Hrvatskoj 1999. i 2008. godine. Društvena istraživanja 19 (1-2): 3-27.

Dale, Gareth. 2012. The Growth Paradigm: A Critique. International Socialism Journal 134: 55-88.

D’Alisa, Giacomo, and Claudio Cattaneo. 2013. Household Work and Energy Consumption: A Degrowth Perspective: Catalonia’s Case Study. Journal of Cleaner Production 38: 71-79.

D’Alisa, Giacomo, Federico Demaria, and Giorgos Kallis (eds.). 2014. Degrowth: A Vocabulary for a New Era. Abingdon: Routledge. 
Drews, Stefan, and Jeroen CJM van den Bergh. 2016. Public Views views on Economic Growth, the Environment and Prosperity: Results of a Questionnaire Survey." Global Environmental Change 39: 1-14. DOI: https://doi.org/10.1016/j.gloenvcha.2016.04.001

Domazet, Mladen. 2019. Degrowth-compatible Common Senses in Croatia. Südosteuropa Mitteilungen 05-06: 158-168.

Domazet, Mladen, and Dinka Marinović Jerolimov (eds.). 2014. Sustainability Perspectives from the European Semi-Periphery. Zagreb: Institute for Social Research.

EVS. 2015. European Values Study Longitudinal Data File 1981-2008 (EVS 1981-2008). GESIS Data Archive, Cologne. ZA4804 Data file Version 3.0.0, doi:10.4232/1.12253

Eysenck, Hans Jurgen. 1954. The Psychology of Politics. NJ: Transaction Publishers.

Gramsci, Antonio. 2007. Prison Notebooks: Selections. London, UK: Lawrence \& Wishart Limited.

Jasanoff, Sheila. 2015. Science and Technology Studies. In: Karen Cackstrand and Eva Lovrbrand (eds.), Research Handbook on Climate Governance. Cheltenham, UK: Edward Elgar Publishing, 36-48.

Kallis, Giorgos. 2018. Degrowth. Newcastle upon Tyne: Agenda publishing.

Latour, Bruno. 1993. We Have Never Been Modern. Cambridge, MA: Harvard University Press.

Mannheim, Karl. 1949. Ideology and Utopia. London: Routledge and Kegan Paul.

Malm, Andreas. 2016. Fossil capital: The Rise of Steam Power and the Roots of Global Warming. London, UK: Verso Books.

Moore, Jason.W. 2015. Capitalism in the Web of Life. London, UK: Verso Books.

Purdey, Stephen J. 2010. Economic Growth, the Environment and International Relations: The Growth Paradigm. Abingdon: Routledge.

Simkus, Albert, and Kristen Ringdal. 2016. The Aftermath of War: Experiences and Social Attitudes in the Western Balkans. Abingdon: Routledge.

Steffen, Will, Paul J. Crutzen, and John R. McNeill. 2007. The Anthropocene: are humans now overwhelming the great forces of nature. AMBIO: A Journal of the Human Environment 36 (8): 614-621. DOI: https://doi.org/10.1579/0044-7447(2007)36[614:TAAHNO]2.0.CO;2

Tsing, Anne L. 2005. Friction: An Ethnography of Global Connection. Princeton: Princeton University Press.

Wallerstein, Immanuel. 1998. The Rise and Future Demise of World-Systems Analysis. Review (Fernand Braudel Center) (1998): 103-112.

Waring, Marilyn. 1999. Counting for Nothing: What Men Value and What Women are Worth. University of Toronto Press.

Wark, McKenzie. 2015. Molecular Red: Theory for the Anthropocene. London, UK: Verso Books.

\section{VREDNOTE, KI SO LAHKO PODLAGA TRANSFORMACIJAM DRUŽBENO- POLITIČNEGA SISTEMA}

Avtorji obravnavajo odnose, vrednote in ideologije, ki labko potencialno vplivajo na kulturne spremembe $k$ bolj okoljsko in socialno trajnostnemu družbeno-političnemu sistemu. Glavni okvir razprave je paradigma odrasti, rezultati analiz na "hrvaškem " primeru pa temeljijo na 
dveh modulih mednarodnega programa socialnega raziskovanja v letu 2017. Glavni kazalnik (kulturnih) potencialov novega razvoja je "lestvica odrasti«, sestavljena iz treh razsežnosti, povezanih s (1) prepoznavanjem potrebe po koncu gospodarske rasti, (2) prepoznavanjem potrebe družbe, da se zgodi socialna sprememba, in (3) spriznanjem, da naj bo družba manj materialistično usmerjena. Te razsežnosti so v razpravi statistično kontekstualizirane glede na socialno-demografske značilnosti anketirancev, njihove vrednote in odnos do ekonomije, socialne pravičnosti in neenakosti, do vloge vlade, demokracije in skrbi za okolje. Rezultati so pokazali, da na Hrvaškem starejše generacije bolj podpirajo stališča ideologije odrasti; hkrati pa je mogoče zaznati, da je potencial za razvoj odnosa do odrasti prisoten v celotni populaciji. Ugotovitve podpirajo teoretično predstavo, da ideologija odrasti zahteva na eni strani prerazporeditev gospodarstva, na drugi pa izraža potrebo po spodobnem življenju za vse člane družbe. V tem okviru so pomembni dejavniki skrb za prijatelje, za okolje in nematerialni vidiki vsakdanjega življenja, npr. umetnost in kultura. Glede teh vprašanj ni niti na levem niti desnem političnem spektru bistvenih razlik; vsekakor pa se usaj na Hrvaškem zdi, da so za ta vprašanja nekoliko občutlivejše leve stranke, a to bo treba posebej raziskati. Predstavljeni instrumenti, analize in raziskave ideologije odrasti so lahko uporabni v prihodnjih raziskavah; cilj je oblikovati shemo stalǐ̌č, ki bi jih bilo treba razviti in npr. z izobraževanjem, zagovorništvom in političnimi ukrepi podpirati v vsaki družbo, ki si prizadeva za kulturno preobrazbo v družbo odrasti.

Dr. sc. Marija Brajdić Vuković, Senior Research Associate, Centre for Research in Social Inequalities and Sustainability (CIDNO), Institute for Social Research in Zagreb, Frankopanska 22, 10000 Zagreb, Croatia, marija@idi.hr

Dr. sc. Branko Ančić, Research Associate, Centre for Research in Social Inequalities and Sustainability (CIDNO), Institute for Social Research in Zagreb, Frankopanska 22, 10000 Zagreb, Croatia, branko@idi.hr

Dr. sc. Mladen Domazet, Head of Research, Institute for Political Ecology, Preobraženska ulica 2, 10000 Zagreb, Croatia, mladen@ ipe.hr

This research was part of the International Social Survey Programme (ISSP) - The Role of Government and Networks modules conducted in Croatia in 2017. ISSP is an on-going programme of cross-national research that covers a range of topics important within the social sciences. Since 2005 Croatia has been represented by Institute for Social Research in Zagreb. The research on the 'degrowth scale' was conducted in partnership with the Institute for Political Ecology's degrowth research stream. Research and programmatic activities of the Institute for Political Ecology are performed in cooperation with Heinrich Böll Stiftung in Berlin and Prague. 